\title{
Distance education learning environments during COVID-19 pandemic from student perspectives: A study in Turkish higher education
}

\author{
Soner Arık \\ Niğde Ömer Halisdemir University, Turkey
}

\begin{abstract}
This research aims to examine the opinions of Turkish higher education students who receive distance education compulsorily due to the COVID-19 pandemic about the distance education learning environments. The data were collected through Distance Education Learning Environments Scale-Turkish Version (DELES-TR) from 3,025 students in 75 different departments at 66 Turkish universities. The study is designed within descriptive survey method. The data were analyzed using independent t-test and oneway ANOVA tests. The results showed that students were indecisive about the distance education learning environments in general and its two sub-dimensions namely 'Personal Relevance and Authentic Learning' and 'Student Interaction and Collaboration' while they partially agreed on 'Active learning and Student Autonomy' and 'Instructor Support'. The results also showed that student opinions about Student Interaction and Collaboration differed significantly in favor of those who received distance education in online learning environments. Students reported that they would prefer online learning environments if they were given the opportunity to choose between in-person and online education, and their opinions differed significantly in favor of those who had access to the distance education via a laptop computer. Further results are discussed within the related literature and several recommendations are made accordingly.
\end{abstract}

Keywords: Distance education; COVID-19; Learning environments; Higher education; Student interaction

Article History: Submitted 20 January 2021; Revised 8 April 2021; Published online 27 May 2021

\section{Introduction}

Human history is full of contagious diseases of different content and effect levels. Contagious diseases, which have affected not only infected individuals but also the whole society from different perspectives (Parıldar, 2020), are classified as outbreak, epidemic and pandemic depending on their domains. In the medical literature, an outbreak is defined as the clear higher incidence of an infectious disease than expected in a particular community, region or season (Hacımustafaoğlu \& Önürmen, 2018). An epidemic, which is expressed as the spread of a disease to a vast number of people in a certain population rapidly, is called a pandemic when it spreads

Address of Corresponding Author

Soner Arık, PhD, Niğde Ömer Halisdemir University, School of Foreign Language, 51240, Niğde, Turkey.

$\triangle$ arik_soner@hotmail.com

0000-0002-5338-9238

How to cite: Arık, S. (2021). Distance education learning environments during COVID-19 pandemic from student perspectives: A study in Turkish higher education. Journal of Pedagogical Research, 5(2), 103-118. http:/ / dx.doi.org/10.33902/JPR.2021269494 
rapidly to different regions and continents (Selvi, 2012). In other words, the main reason for defining an epidemic as a pandemic is expressed as spreading to more than one continent or all over the world (Hays, 2005). Today, global travel and migration movements cause epidemics to transform into pandemics really fast.

A current example of such a transformation is the COVID-19 virus outbreak, which emerged in Wuhan, China on December 1, 2019, (Jiang \& Xu, 2021) and rapidly turned into an epidemic and a pandemic subsequently (Frutos et al., 2020). In this process, each country had to enforce different measures such as nationwide quarantine, curfew, national emergency, etc. Besides, considering to close schools as a useful precaution to prevent the spread of infectious diseases (Braunack-Mayer et al., 2013; Anderson et al., 2020), many countries also interrupted face-to-face education in schools and replaced it with distance education (Di Domenico et al., 2020).

Similarly, all public and private schools in Turkey were closed on March 16, 2020 and the whole country switched to distance education (Ministry of National Education [MoNE], 2020). Although it is still debated whether distance education can replace face-to-face education (Zhang et al., 2020), students have been continuing their education in distance education learning environments since then. Felix (2001) suggests that students who study in online learning environments voluntarily benefit from these environments more than the others. However, under the current conditions, students have no choice but to receive distance education compulsorily, which makes it important to take the opinions of students about their distance education learning environments.

\subsection{Literature Review}

Distance education, which became an important part of the curricula in the late 1970s (Sewart et al., 2020), is a computer-based teaching method where any student interaction takes place outside the classroom (Moore et al., 2011). Researchers claim that distance education saves students from transportation problems and relieves them economically by reducing their expenditures (Traxler, 2018; Umek et al., 2015). In addition, some claim that distance education can be as effective as formal education (Bernard et al., 2004) and that students can achieve equal (Jahng et al., 2007; Machtmes \& Asher, 2000; Shachar \& Neumann, 2003) or even more (Zhao et al., 2004) academic success in distance education.

However, in the current pandemic period, the possible negative consequences of closing schools and replacing face-to-face education with distance education compulsorily should also be addressed. Many countries had to switch to distance education nationwide without having enough time and opportunity to make up their shortages in terms of readiness for distance education, which is a multidimensional condition varying from learning motivation (Fairchild et al., 2005) and self-efficacy related to using computer and internet (Hung et al., 2010) to the self-efficacy related to communicating in an online learning environment (Roper, 2007).

When people involved in the distance education (students, teachers, etc.) do not have the required education and readiness, the distance education learning environments are to be shaped during the learning-teaching process (Kaufman \& Buckner, 2019). In this case, it is essential to consider how students can adapt to and gain from distance education satisfactorily because students' interactions and collaborations with teachers (Kaufmann \& Tatum, 2017) and other students (Bernard et al., 2009) differ in the context of face-to-face education and distance education. Therefore, our knowledge and experience in face-to-face education may not be fully applicable to distance education practices (Sellnow \& Kaufmann, 2017).

It is suggested that distance education affects students' participation, or engagement, in learning activities as well (Czerkawski \& Lyman, 2016; Richardson, 2020). One-way information flow from teacher to students is not sufficient in distance education (Mattar, 2018) and active participation of students in learning activities should be increased through multi-faceted communication and various interaction opportunities (Wallace, 2003). However, implementing active learning strategies and techniques in distance education is not as easy as in face-to-face education (Considine \& Dean, 2003). Visual and auditory interactions between students and 
teachers happen naturally and simultaneously in face-to-face education (Hirumi, 2002), but it is necessary to provide appropriate communication tools and opportunities to ensure such interaction in distance education (Bernard et al., 2009).

Another factor that must be addressed in distance education is instructor support and feedback. Students who are given the support and feedback to evaluate their learning processes and outcomes in face-to-face education need personal and individual feedback from the instructor rather than just technology-based feedback in distance education learning environments (Weinhandl et al., 2020). That is because, through such feedback and support, instructors ensure that students actively engage in learning activities (Martin \& Dowson, 2009).

Distance education is a planned educational system requiring various written, audio or audiovisual materials, tools, communication technologies and methods (İsman, 2011) and it can be accessed by internet or web-based technologies (Dabbagh \& Bannan-Ritland, 2005). Designers of distance education learning environments should consider the constantly changing needs of students regarding these tools, technologies and methods (Cronje, 2016) and select appropriate ones to transfer course contents to students by taking the interactions between students and instructors into account (SOU Distance Education Center, 2009).

Putting forward a conversational approach, Laurillard (2000) states that especially university education should enable student interaction with other students, instructors and the content. The communication and interaction of students in distance education learning environments is considered essential in terms of not only students' academic achievement, personality development (Kareal \& Klema, 2006) or individual learning (Kaymak \& Horzum, 2013), but also their satisfaction with the distance education learning environments (Lesht \& Schejbal, 2020). This satisfaction from, or trust in, the learning environments in turn affects their achievements, interaction and attitudes (Haar, 2018).

Students are also provided with individual, flexible and independent learning environments in distance education (Cerezo et al., 2010; Delen et al., 2014; Uşun, 2006). This is essential in distance education as students' perceptions about their autonomy and participation in decision making processes have positive effects on their academic performances (Wayne et al., 2013). Başar and colleagues (2019) state that students' perceptions and opinions about the distance education process are considered as the main factors affecting the efficiency of distance education. Therefore, students' opinions and perceptions about distance education learning environments are vital for achieving the educational goals by continuing the process in a healthy and effective way.

The COVID-19 pandemic led to an unexpected total transition to distance education in Turkey, like the rest of the world. From primary to high school, the Turkish MoNE developed a common plan of action and imposed it throughout the country for all grade levels. However, as for the Higher Education, every university planned their own distance education programs. The instructors in these universities were caught unprepared and had to get accustomed to this new and unexpected condition rapidly. In this sense, it would be useful to shed light on the distance education learning environments in terms of "personal relevance and authentic learning", "teacher support", "active learning and student autonomy", and "student interaction and cooperation" through students' opinions.

In addition to contributing to the related literature, the study is designed to raise worldwide scientific interest in conducting qualitative or mixed-method studies to investigate the distance education learning environments so that effective methods and strategies can be developed to ensure 'personal relevance and authentic learning', 'teacher support', 'active learning and student autonomy', and 'student interaction and cooperation' in distance education learning environments.

Many research studies have been conducted on distance education during the COVID-19 pandemic period (Abbasi et al., 2020; Alan et al., 2020; Asio \& Bayucca, 2021; Boggiano et al., 2020; Drucker \& Fleischhauer, 2021; Hebebci et al., 2020; Kaufmann \& Vallade, 2020; Klapproth et al., 2020; Miralay, 2020; Muthuprasad et al., 2020; Sakarya \& Zahal, 2020). However, these studies have 
mostly investigated students' perceptions about distance education. The difference and significance of this study is that it aims to determine students' views about learning environments in distance education specifically rather than focusing on distance education in general. In addition, it is thought that the study will reveal more generalizable results compared to similar studies due to the large size of its sampling.

\subsection{Research Problem}

This study aims to examine the opinions of the Turkish higher education students, who have been receiving distance education as a compelled substitute for face-to-face education due to the COVID-19 pandemic, about the distance education learning environments. As Richardson et al. (1999) stated, variables such as gender, age, and prior education are essential in evaluating online learning programs and environments as they affect students' academic achievements in and preferences between distance and face to face learning environments. So, these variables were taken into account in this study.

A compulsory switch to distance education, which has been put into action in Turkey and throughout the world for the first time in history, has resulted in new problems regarding the efficiency and quality of education. Therefore, it is considered important to reveal the Turkish higher education students' opinions about their experiences in distance education learning environments as they have been receiving distance education since March 16, 2020. In this context, the following questions were sought:

1. What are Turkish higher education students' opinions about distance education learning environments?

2. Do Turkish university students' opinions about;

a. distance education learning environments,

b. personal relevance and authentic learning,

c. teacher support,

d. active learning and student autonomy,

e. student interaction and cooperation,

differ significantly in terms of;

- receiving education online or offline,

- their preference to receive education online or offline,

- the resource through which they access distance education,

- the tools with which they access to lessons in the distance education environment.

\section{Method}

\subsection{Research Design}

The study is designed as a quantitative research study using a descriptive design with a survey as the primary data gathering instrument. Quantitative research serves to explain certain phenomena through numerical data analyzed with mathematical or statistical methods (Aliağa \& Gunderson, 2002). In descriptive research, researcher aims only to describe individuals, events, or conditions by studying them as they are in nature without manipulating any of the variables (Houser, 2008). Survey method is a quantitative research approach aiming to describe a past or present case, individual or object as it is and within its own conditions (Karasar, 2006) and it enables researchers to investigate for insight into a particular situation that occurs within a specified time (Aypay, 2020).

\subsection{Sampling}

The sampling of the study consists of 3025 university students who studied in 75 different departments of 66 Turkish universities between June 2020 and December 2020. The participants are comprised of 2095 female and 930 male students. 


\subsection{Data Collection Tools and Procedure}

In this study, the data was collected through the Distance Education Learning Environments ScaleTurkish version (DELES-TR). The original scale, called the Distance Education Learning Environments Scale (DELES) was developed by Walker (2003) and the Turkish version used in this research was adapted into Turkish by Özkök et al. (2009). As a result of the confirmatory factor analysis (CFA) of the version of the scale developed for the Turkish higher education context, it was concluded that the scale, which consisted of 34 items in 6 dimensions, was valid and the Cronbach alpha score proved that it was also reliable (Özkök et al., 2009). The dimensions of the scale were named as Instructor Support with 8 items, Student Interaction and Collaboration with 6 items, Personal Relevance with 7 items, Authentic Learning with 5 items, Active Learning with 3 items and Student Autonomy with 5 items. The scale was a 5-likert type one from 1 (totally disagree) to 5 (totally agree) and had no reversed items.

In order to use this scale, permission was requested from the researcher via e-mail and the ethics committee approval was obtained from the Ethics Committee of Niğde Ömer Halisdemir University. As the scale could not be applied face to face due to pandemic conditions, it was published online via Google forms and announced to the students by university instructors.

\subsection{Validity and Reliability Analysis}

The validity and reliability of the scale were tested within the data obtained from the sampling of the research. The Kaiser-Meyer-Olkin (KMO) value was found to be .973 in the EFA test conducted to test the validity of the scale. Since the Bartlett's Test of Sphericity result was also significant $(p<0.05)$, it was decided that factor analysis could be performed on the scale. In the confirmatory factor analysis, it was concluded that the values of the items in the scale ranged from .588 to .812 and that the scale was comprised of four factors.

Since two of the factors obtained by CFA are combined with the others in this sampling, the expressions in the relevant factors were combined. In this context, the first factor explains $20.97 \%$ of the scale and is entitled Personal Relevance and Authentic Learning. The second factor explains $17.63 \%$ of the scale and is entitled Teacher Support. The remaining factors, entitled Active Learning and Student Autonomy and Student Interaction and Collaboration, explain $16.29 \%$ and $14.57 \%$ of the scale respectively. The entire scale explains $69.46 \%$ of the features to be measured, which shows that the scale is valid.

In the Cronbach alpha test conducted to determine the reliability of the scale, the values of the four dimensions, namely 'Personal Relevance and Authentic Learning', 'Instructor Support', 'Active Learning and Student Autonomy' and 'Student Interaction and Collaboration', were found as $.96, .94, .92$ and .93 respectively. The Cronbach alpha result for the whole scale was found to be .97 , which indicated that the scale was highly reliable. In order to analyze the data obtained from the scales, Skewness and Kurtosis values were examined and it was observed that all variables were normally distributed (between +1.96 and -1.96 ). Thus, normality tests were carried out.

In this study, a quasi-experimental research design is employed in order to determine students' perceptions towards the community of inquiry in terms of cognitive, social, and teaching presence as well as their interaction levels.

\section{Findings}

In this section, the findings regarding the views of Turkish higher education students, who have to continue their education in distance education environments compulsorily due to the COVID-19 pandemic, about distance education environments are included. The data were analyzed by taking different variables into account and the findings are presented based on the research questions and sub-questions respectively. The rank values of this 5-likert type scale were accepted as Disagree between 1 and 1.80, Partly Disagree between 1.81 and 2.59, Not Sure between 2.60 and 3.39, Partly Agree between 3.40 and 4.19, and Agree between 4.20 and 5.00. The whole scale and its dimensions were evaluated based on these values. The results regarding the $1^{\text {st }}$ research question, which is 
"What are the opinions of Turkish higher education students about distance education learning environments?", are presented in Table 1.

Table 1

Distance education learning environment views of Turkish higher education students

\begin{tabular}{lllllll}
\hline Dimensions & $N$ & Min & Max & Mean & SD & Agreement \\
\hline Personal Relevance and Authentic Learning & 3025 & 1.00 & 5.00 & 3.25 & 1.13 & Not sure \\
\hline Instructor Support & 3025 & 1.00 & 5.00 & 3.50 & 1.14 & Partly agree \\
\hline Active Learning and Student Autonomy & 3025 & 1.00 & 5.00 & 3.64 & 1.04 & Partly agree \\
\hline Student Interaction and Collaboration & 3025 & 1.00 & 5.00 & 2.71 & 1.27 & Not sure \\
\hline Whole Scale & 3025 & 1.00 & 5.00 & 3.30 & .96 & Not sure \\
\hline
\end{tabular}

Table 1 shows that the students were "Not sure" about 'Personal Relevance and Authentic Learning', 'Student Interaction and Collaboration', and the whole scale. This finding means that students did not have negative or positive opinions about their distance education learning environments in general. Also, they were not sure whether distance education learning environment supported students' personal relevance and provided opportunities for authentic learning, and interaction and collaboration between students. On the other hand, they partially agreed about 'Active learning and Student Autonomy' and 'Instructor Support'. In this context, it can be stated that students think they, to some extent, receive instructor support and are provided with active learning and student autonomy opportunities. Findings related to the $1^{\text {st }}$ sub-problem of the $2^{\text {nd }}$ research question, which aims to examine the participants' opinions in terms of whether they receive education on-line or off-line, are given in Table 2.

Table 2

T-test results on the views on distance education learning environment

\begin{tabular}{|c|c|c|c|c|c|c|}
\hline Dimensions & Modality & $N$ & Mean & $S D$ & $t$ & $p$ \\
\hline \multirow{2}{*}{$\begin{array}{l}\text { Personal Relevance and Authentic } \\
\text { Learning }\end{array}$} & Online & 1955 & 3.26 & 1.13 & \multirow[t]{2}{*}{1.219} & \multirow[t]{2}{*}{.223} \\
\hline & Offline & 1070 & 3.21 & 1.12 & & \\
\hline \multirow{2}{*}{ Instructor Support } & Online & 1955 & 3.57 & 1.12 & \multirow[t]{2}{*}{4.755} & \multirow[t]{2}{*}{$.000^{*}$} \\
\hline & Offline & 1070 & 3.36 & 1.16 & & \\
\hline \multirow{2}{*}{$\begin{array}{l}\text { Active Learning and Student } \\
\text { Autonomy }\end{array}$} & Online & 1955 & 3.62 & 1.03 & \multirow[t]{2}{*}{1.176} & \multirow[t]{2}{*}{.240} \\
\hline & Offline & 1070 & 3.67 & 1.05 & & \\
\hline \multirow{2}{*}{$\begin{array}{l}\text { Student Interaction and } \\
\text { Collaboration }\end{array}$} & Online & 1955 & 3.26 & 1.13 & \multirow[t]{2}{*}{3.655} & \multirow[t]{2}{*}{$.000^{*}$} \\
\hline & Offline & 1070 & 3.21 & 1.12 & & \\
\hline \multirow{2}{*}{ Whole Scale } & Online & 1955 & 3.57 & 1.12 & \multirow[t]{2}{*}{2.381} & \multirow[t]{2}{*}{$.017^{*}$} \\
\hline & Offline & 1070 & 3.36 & 1.16 & & \\
\hline
\end{tabular}

${ }^{*} p<0.05$

According to Table 2, students' opinions regarding distance education learning environment as a whole as well as the 'Instructor Support' and 'Student Interaction and Collaboration' dimensions show a statistically significant difference based on the type of distance education they receive online or offline distance education. The difference is found to be in favor of the ones who receive online distance education. This means that, while those who received distance education offline did not have a negative or positive opinions about their distance education learning environments, the students who received distance education online favored their distance education learning environments as a whole. In addition, they agreed that their online learning environments provided them with instructor support, and student interaction and collaboration to some extent. Table 3 presents the findings about the $2^{\text {nd }}$ sub-problem of the $2^{\text {nd }}$ research question, which examines students' preferences between online or offline distance education. 

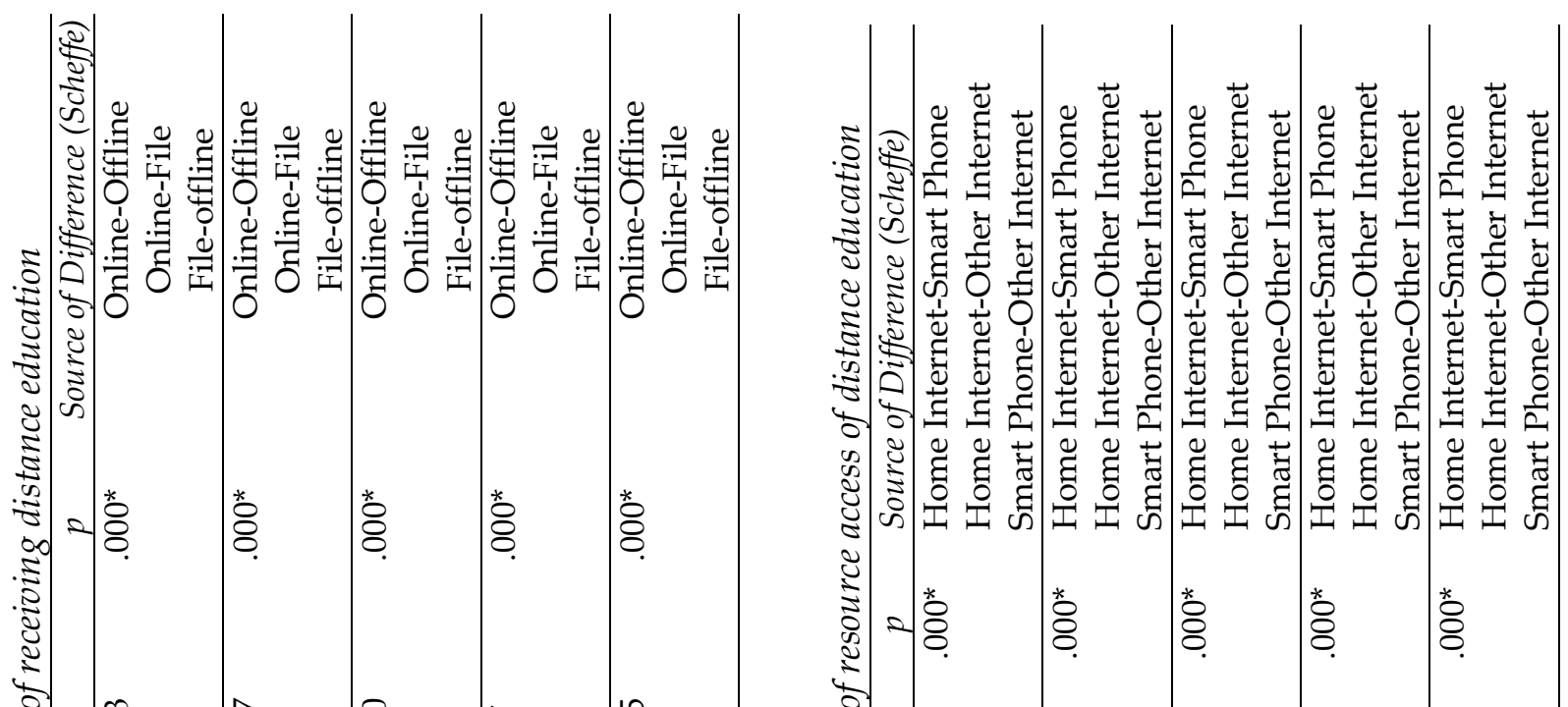

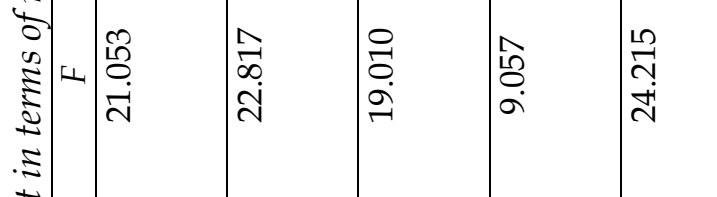

$\frac{5}{5}$
$\frac{5}{5}$
$\frac{5}{5}$

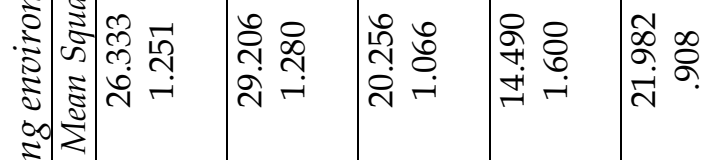

密

.

$\frac{\sqrt{2}}{3}$

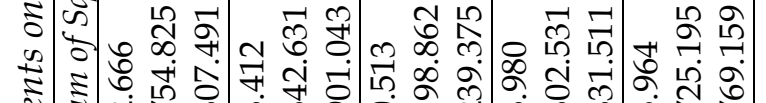

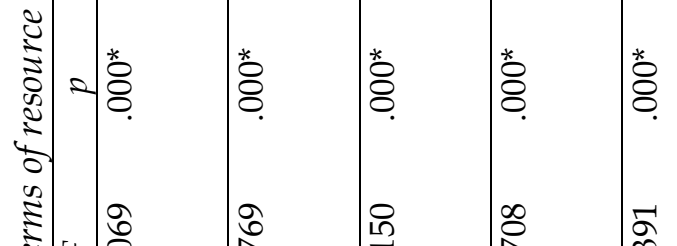

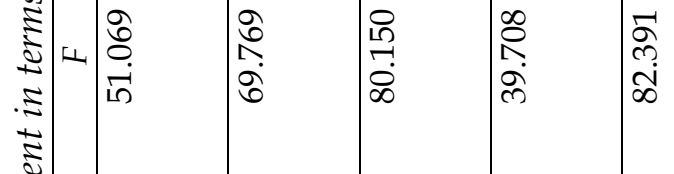

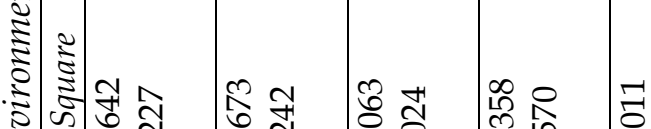

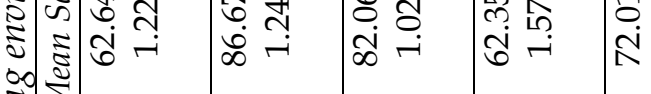

.

$\stackrel{2}{2}$

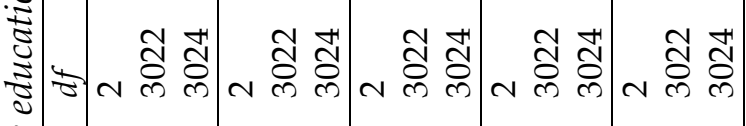

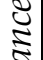

$\frac{\substack{0 \\ \frac{\pi}{5}}}{3}$

ธิ

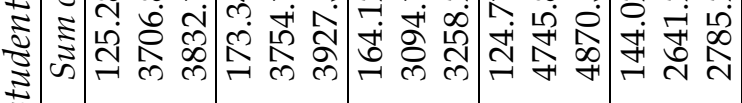

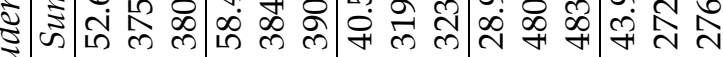

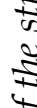

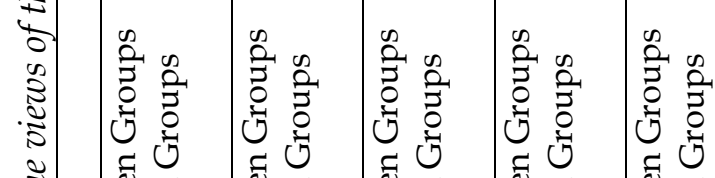

₹

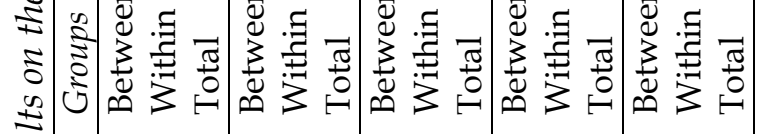

20.

$\stackrel{2}{2}$

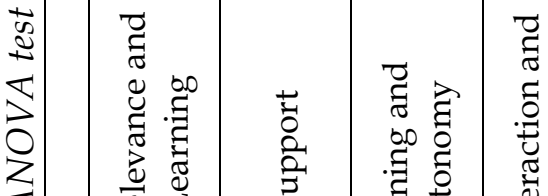

उ.

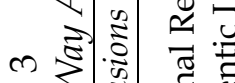

定

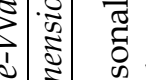

苟

过焉

\section{垔}

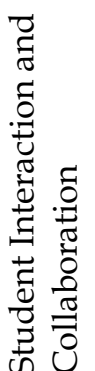

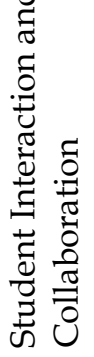

$\stackrel{2}{2}$

के की

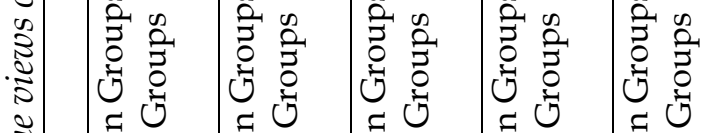
ई

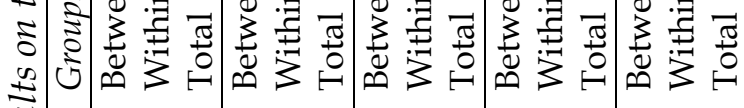
ป

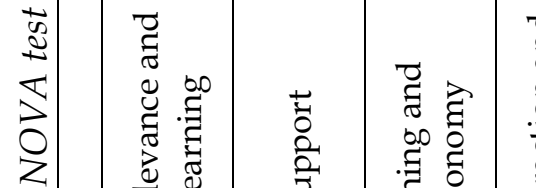

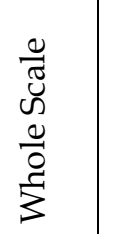

Z

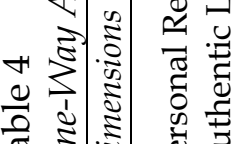

范

O ค \& 
Table 3 shows that Turkish Higher Education students' opinions regarding distance education environments and the four dimensions of the scale differ significantly in terms of their preferences about how to receive distance education. The results of the Scheffe test, which was conducted to determine the source of the difference, revealed that the average score of the participants who would prefer to take courses online is higher than those of the other participants regarding the whole scale and all its dimensions. This indicates that students who prefer online distance education had more positive opinions about distance education learning environment both as a whole and in terms of its dimensions. Also, there is a statistically significant difference between students' opinions in terms of their preference between receiving distance education offline and through files uploaded. The difference was in favor of those who prefer distance learning through files uploaded. In other words, students preferred to use uploaded files in distance education learning environments rather than receiving offline education. The 3rd sub-problem of the 2nd research question was about the students' opinions on distance education learning environments in terms of the resource of their access to distance education. The results of this sub-problem are given in Table 4.

Table 4 represents that the views of Turkish higher education students on distance education learning environments and the sub-dimensions of the scale show a statistically significant difference in terms of the source of their access to distance education. According to the results of the Scheffe test, the average score of those who access to distance education via the Internet from their houses is higher in the entire scale and all its sub-dimensions than that of the participants who receive distance education via mobile phone internet packages and other internet providers/resources (e.g. from the homes of relatives/neighbours). As for the difference between access to distance education via mobile phone internet packages and other internet resources, it is concluded that the average score of the participants who receive distance education via mobile phone internet packages is higher than that of the participants who have access to distance education via other internet. Findings regarding the 4th sub-problem of the 2 nd research question, which investigates the participants' opinions on distance learning environments in terms of the tools they use to access to distance education, are given in Table 5.

Table 5

One -Way ANOVA test results on the views of the students on distance education learning environment in terms of distance education tools/gadgets

\begin{tabular}{|c|c|c|c|c|c|c|c|}
\hline Dimensions & Groups & $\begin{array}{l}\text { Sum of } \\
\text { Squares }\end{array}$ & $d f$ & $\begin{array}{l}\text { Mean } \\
\text { Square }\end{array}$ & $F$ & $p$ & $\begin{array}{l}\text { Source of Difference } \\
\text { (Scheffe) }\end{array}$ \\
\hline \multirow{3}{*}{$\begin{array}{l}\text { Personal } \\
\text { Relevance and } \\
\text { Authentic } \\
\text { Learning }\end{array}$} & Between Groups & 57.504 & 3 & 19.168 & 15.341 & $.000^{*}$ & \multirow{3}{*}{$\begin{array}{l}\text { Laptop computer- } \\
\text { Smart phone }\end{array}$} \\
\hline & Within Groups & 3774.605 & 3021 & 1.249 & & & \\
\hline & Total & 3832.109 & 3024 & & & & \\
\hline \multirow[b]{2}{*}{$\begin{array}{l}\text { Instructor } \\
\text { Support }\end{array}$} & Between Groups & 78.409 & 3 & 26.136 & \multirow[t]{2}{*}{20.513} & $.000^{*}$ & \multirow{2}{*}{$\begin{array}{l}\text { Laptop computer- } \\
\text { Smart phone }\end{array}$} \\
\hline & $\begin{array}{l}\text { Within Groups } \\
\text { Total }\end{array}$ & $\begin{array}{l}3849.096 \\
3927.505\end{array}$ & $\begin{array}{l}3021 \\
3024\end{array}$ & 1.274 & & & \\
\hline \multirow{3}{*}{$\begin{array}{l}\text { Active Learning } \\
\text { and Student } \\
\text { Autonomy }\end{array}$} & Between Groups & 62.825 & 3 & 20.942 & \multirow[t]{3}{*}{19.799} & $.000^{*}$ & \multirow{3}{*}{$\begin{array}{l}\text { Laptop computer- } \\
\text { Smart phone }\end{array}$} \\
\hline & Within Groups & 3195.421 & 3021 & 1.058 & & & \\
\hline & Total & 3258.247 & 3024 & & & & \\
\hline \multirow{3}{*}{$\begin{array}{l}\text { Student } \\
\text { Interaction and } \\
\text { Collaboration }\end{array}$} & Between Groups & 72.732 & 3 & 24.244 & \multirow[t]{3}{*}{15.266} & $.000^{*}$ & \multirow{3}{*}{$\begin{array}{l}\text { Laptop computer- } \\
\text { Smart phone }\end{array}$} \\
\hline & Within Groups & 4797.833 & 3021 & 1.588 & & & \\
\hline & Total & 4870.566 & 3024 & & & & \\
\hline \multirow{3}{*}{ Whole Scale } & Between Groups & 65.152 & 3 & 21.717 & \multirow[t]{3}{*}{24.119} & $.000^{*}$ & \multirow{3}{*}{$\begin{array}{l}\text { Laptop computer- } \\
\text { Smart phone }\end{array}$} \\
\hline & Within Groups & 2720.142 & 3021 & .900 & & & \\
\hline & Total & 2785.295 & 3024 & & & & \\
\hline
\end{tabular}

${ }^{*} p<0.05$

According to the values in Table 5, the views of Turkish higher education students on distance education learning environments significantly differ in the total scale and all its sub-dimensions in 
terms of the tools by which they access to the lessons. The results of the Scheffe test conducted to determine the source of the difference reveal that the average score the participants got from the scale who follow the lessons with a laptop computer are higher than that of the participants who receive distance education with a smart phone. This finding shows that, compared to those who receive distance education with a smart phone, students who receive distance education with a laptop had more positive opinions about distance education learning environments.

\section{Discussion and Conclusion}

\subsection{Student Opinions about Distance Education Learning Environments}

The first research question of the study investigates the opinions of Turkish Higher Education students, who continue their education in distance education learning environments compulsorily due to the COVID-19 pandemic, on distance education learning environments. According to the results of the research, students are generally indecisive about distance education learning environments, which indicates that they are not sure whether distance education learning environments are qualified or not in terms of providing teacher support, enabling student communication and collaboration, addressing personal relevance, and supporting authentic (realistic) learning, active learning, student autonomy and satisfaction. Similar results were obtained in three different studies conducted during the COVID-19 pandemic process in which this study was also conducted (Alan et al., 2020; Boggiano et al., 2020; Karakuş, et al., 2020). Boggiano et al. (2020) concluded that university students are concerned about the quality of their education and that some participants of the study thought of even taking a break from their studies for a semester and waiting until they receive quality face-to-face education again. Alan et al. (2020) also revealed that students' perceptions about distance education are negative (below average). Karakuş et al. (2020) found that students generally have negative perceptions and views about distance education practices. Finding similar results, Özüdoğru and Hişmanoğlu (2016), Inozu and Ilin (2007), and Abbasi et al. (2020) also concluded that students expressed negative opinions against distance education learning environments and that they would prefer face-to-face education environments if they were given the opportunity to choose. Erfidan (2019) also found in his study that majority of the students' had negative views or were indecisive, which supports the result of the present study.

However, in another study conducted before COVID-19 pandemics, Srichanyachon (2013) concluded that students' attitudes towards online learning environments were moderate. Although published in 2020, in another study conducted in the pre-COVID-19 period, Karakış (2020) found that students had positive opinions about all the dimensions of distance education learning environments including teacher support, student communication and collaboration, personal relevance, authentic (realistic) learning, active learning, student autonomy and satisfaction. This information from the literature suggest that it is possible to claim that students' views on distance education learning environments have decreased from medium or above medium level in the pre-pandemic period to below medium levels in the current COVID-19 pandemic period, during which students are made to receive education through distance education learning environments compulsorily. The fact that students receive education via distance education learning environments compulsorily during the current COVID-19 pandemic period may be the reason for their negative opinions.

As for the dimensions of distance education learning environments, it was concluded that the students were not sure whether distance education learning environments supported 'Personal Relevance and Authentic Learning' and 'Student Interaction and Collaboration' dimensions. Similarly, the findings from Karakuş and colleagues' study (2020) also revealed that students do not have positive opinions about communication, interaction, group work and cooperation in online learning environments. Likewise, Miralay (2020), and Parkes and Barrs (2020) also stated that, in distance education learning environment, students expressed negative opinions about interaction in distance education learning environments. 
Another result obtained in the context of the scale dimensions is that students receive teacher support and are provided with active learning and student autonomy opportunities to some extent. Sakarya and Zahal (2020), who achieved similar results regarding teacher support, found that students expressed positive opinions on distance education learning environments in the context of asking questions to teachers and receiving feedback from them simultaneously. On the other hand, Muthuprasad et al. (2020) concluded that university students expressed negative opinions about teacher support in terms of feedback. According to the results of the study, students attributed teachers' lack of feedback to their inability to use information communication technologies. The differences between the results of our study and this one might be due to the difference in the sampling used in the studies. In a study conducted in the pre-COVID-19 period, Alqurashi (2019) also mentioned students' negative views on teacher support. In the current period, it is thought that the possibility of teachers being more rigorous due to the lack of compensation for or alternative to distance education may explain the partial participation presented by the students regarding teacher support in this study.

Students also stated that distance education learning environment supported their personal relevance and provided authentic learning opportunities partially. Personal Relevance and Authentic Learning is among the dimensions that were positively commented in the pre-COVID19 period as well. For example, Hebebci et al. (2020) revealed that personal relevance and authentic learning were the dimensions that had the strongest correlation with students' satisfaction in distance education learning environments.

\subsection{Student Opinions in terms of Receiving Education Online or Offline}

Another research question of the study is about whether students' views on distance education learning environments differ depending on whether they received distance education online or offline. The results showed that there is a statistically significant difference between students' opinions regarding the whole scale and its two dimensions, Teacher Support and Student Interaction and Collaboration, based on how they received distance education. The mean scores of students who received distance education online were higher in the whole scale and the dimensions 'Teacher support' and 'Student Interaction and Collaboration'. In this sense, it can be stated that, when the students are offered education through online learning environments, they find distance education learning environments beneficial in general, and specifically in terms of providing teacher support and enabling student interaction and collaboration. This result proves that teacher support is partially addressed in the online learning environments in which the participants of this study received their education. This was a contribution to existing literature, as there was not any other study that examined students' views on distance education learning environments in terms of taking distance education online or offline.

\subsection{Student Opinions in terms of Type of Distance Education Learning Environment Preference}

The students' views were also examined in terms of whether they would prefer to receive distance education in online, offline or file-uploaded learning environments if they had a choice. The results revealed that the opinions of students differ statistically in terms of the choice they would make if they had a choice in favor of online education. In other words, the average score of those who wanted to receive distance education online was higher than the average of those who preferred distance education offline or by uploading files to the system in the entire scale and all its dimensions. In addition, as for distance education preference offline or through files being uploaded to the system, there was a statistically significant difference against offline learning environments. Thus, it appears that students prefer online learning environments as a distance education learning environment and consider a learning environment that consists of uploading files to the system as a second choice in their preferences. The reason why students primarily prefer online learning environment might be due to the fact that online education environment is the closest learning environment to face-to-face education environment among the three options regarding social interaction. On the other hand, the ease of accessing to the educational materials 
and the availability of such uploaded files by printing or copying them might be the reason why they prefer to be taught through files being uploaded to the system as a second choice. Our interpretations are solely based on the findings of our study, because we did not find any studies in the literature that examined the preferences of university students among distance learning environments designed as online, offline and through file upload.

\subsection{Student Opinions in terms of the Resource of Access to Distance Education}

Source of student access to distance education learning environments was also addressed in the study. The results of the research revealed that students' views on distance education learning environments differ significantly in favor of those who connect to the internet from home in the whole scale and in all its dimensions. In other words, it is understood that students who connected to the Internet from home tend to have a more positive view of distance education learning environments compared to those who connected to distance education via their mobile phone internet packages or other internet connections. It can be stated that this is a result of the continuity and quality of the internet connection. Similarly, Barış (2015) also claims that having a continuous and quality internet access may affect student perceptions about distance education.

\subsection{Student Opinions in terms of the Tools for Access to Distance Education}

The final variable mentioned in this study is the tools students used for access to distance education learning environments. According to the results of the study, student views showed statistically significant differences in favor of those who connected to distance education through their laptop computer in all dimensions and in the entire scale when compared with those who used smart phones. In other words, views of students who connect to distance education learning environments using laptop computers were more positive. This coincides with the results of the study by Barış (2015) who claims that having a laptop positively affects student perceptions about distance education. In this case, it seems that having to participate in distance education through smart phones affects students' opinions negatively. An explanation for this finding could be that smart phones have screens that are not large enough to follow distance education efficiently.

\section{Recommendations}

Based on the results obtained in this study, it is thought that the following recommendations will be useful in increasing the efficiency of distance education learning environments.

$>$ Considering that the Turkish Higher Education students in this study are indecisive about their distance education learning environments, it is recommended that they be included into the course design processes by the instructors.

$>$ Seeing that the participants of the study are indecisive about their distance education learning environments in terms of student interaction and collaboration, it can be understood that they find the interaction and collaboration they have insufficient. Therefore, instructors are recommended to make use of different methods, strategies, techniques and activities to enable more interaction and collaboration among students.

$>$ As students in this study are indecisive about their distance education learning environment in terms of Personal Relevance and Authentic Learning, it is likely that they feel the need for more authentic materials and activities that will attract their attention. Therefore, instructors are recommended to design the distance education online environments in such a way to appeal to the realities of daily life and to attract students' personal interests.

$>$ Participants of the study are seen to be indecisive about Student Interaction and Collaboration in their distance education learning environments. However, collaboration and interaction between students is considered an essential component to be considered in designing successful distance education learning environments. Thus, instructors should redesign the learning environments based on methods and techniques that will enable interaction and collaboration between students. 
$>$ Learning cannot be realized effectively with learners being just passive receivers of knowledge so active participation of students in learning activities should be increased through multi-faceted communication and various interaction opportunities. In this study, participants partially agree with the active learning and student autonomy features of their distance education learning environments. Therefore, it is recommended that instructors should approach the distance education process with a student centered view and redesign the learning environment in such a way to ensure that students are at the heart of the teaching-learning process.

$>$ Participants of the study partially agree on the Instructor Support dimension. Instructors are therefore recommended to design a well-structured feedback and support system in distance education learning environments.

$>$ Instructor support also involves finding solutions to the students' problems during the education process. Therefore, it is thought that teachers also need support to deal with any kind of problems in the distance education learning environments. In this sense, university or faculty managements are recommended to be in close contact with the instructors by setting up committees consisting of experts that will provide technical, pedagogical, psychological, etc. support for the instructors.

$>$ The participants prefer online education rather than offline education or an education with uploaded files to the system. Therefore, instructors are recommended to do their courses online. However, this can be possible only if students have the required tools, internet access, etc. Otherwise, opportunity gaps between students may lead to inequality in education. For example, the results of this study show that not every student has the opportunity to access to the distance education learning environment through laptop and via their home internet connections, both of which are seen to result in positive student opinions in this study. Therefore, instructors should first learn about the conditions of every single student in these senses. Also, setting up their expectations from students accordingly, they should support their online courses in different ways such as files uploaded to the system.

$>$ This study aims to determine the opinions of Turkish Higher education students about the distance education learning environments. It does not try to find out the underlying reasons of their opinions, which are thought to be important in finding out possible deficiencies and weaknesses of distance education programs and learning environments. In this context, it is recommended that qualitative studies should be conducted to investigate the underlying reasons for their opinions and perceptions in depth.

\section{References}

Abbasi, S., Ayoob, T., Malik, A., \& Memon, S. I. (2020). Perceptions of students regarding E-learning during Covid-19 at a private medical college. Pakistan Journal of Medical Sciences, 36(COVID19-S4), 57-61. https://doi.org/10.12669/pjms.36.COVID19-S4.2766

Alan, Y., Biçer, N., \& Can, F. (2020). Perspectives of pre-service teachers on distance education: Covid-19 process. Revista Argentina de Clínica Psicológica, 29(5), 1972-1984. https://doi.org/10.24205/03276716.2020.1193

Aliaga, M., \& Gunderson, B. (2002). Interactive statistics. Virginia: Pearson Education

Alqurashi, E. (2019). Predicting student satisfaction and perceived learning within online learning environments. Distance Education, 40(1), 133-148. https:/ / doi.org/10.1080/01587919.2018.1553562

Anderson, R. M., Heesterbeek, H., Klinkenberg, D., \& Hollingsworth, T. D. (2020). How will country-based mitigation measures influence the course of the COVID-19 epidemic? The Lancet, 395(10228), 931-934. https:// doi.org/10.1016/S0140-6736(20)30567-5

Asio, J.M.R. \& Bayucca, S.A. (2021). Spearheading education during the COVID-19 rife: Administrators' level of digital competence and schools' readiness on distance learning. Journal of Pedagogical Sociology and Psychology, 3(1), 19-26. https:/ / doi.org/10.33902/JPSP.2021364728

Aypay, A. (2020). Araştırma yöntemleri [Research methods]. Anı yayıncılık. 
Barış, M. (2015). Analyzing the University Students' Attitudes Towards Distance Education: Namık Kemal University Case Study. Sakarya University Journal of Education, 5(2), 36-46. https://doi.org/10.19126/suje.38758

Başar, M., Arslan, S., Günsel, E., \& Akpınar, M. (2019). Distance Education Perceptions of Prospective Teachers. Journal of Multidisciplinary Studies in Education, 3(2), 14-22.

Bernard, R. M., Abrami, P. C., Borokhovski, E., Wade, C. A., Tamim, R. M., Surkes, M. A., \& Bethel, E. C. (2009). A meta-analysis of three types of interaction treatments in distance education. Review of Educational Research, 79(3), 1243-1289, https:/ / doi.org/10.3102/0034654309333844

Bernard, R. M., Abrami, P. C., Lou, Y., Borokhovski, E., Wade, A., Wozney, L., Wallet, P. A., Fiset, M., \& Huang, B. (2004). How does distance education compare with classroom instruction? A meta-analysis of the empirical literature. Review of Educational Research 74(3), 379-439. https://doi.org/10.3102/00346543074003379

Boggiano, N., Lattanzi, O., McCoole, M., Bursten, B., \& Hansen, P. (2020). Transitioning during COVID-19: Student perspectives. https:// core.ac.uk/download/pdf/343944408.pdf on 18.02.2021.

Braunack-Mayer, A., Tooher, R., Collins, J. E., Street, J. M., \& Marshall, H. (2013). Understanding the school community's response to school closures during the H1N1 2009 influenza. BMC Public Health, 13 (344), 1-15. https:// doi.org/10.1186/1471-2458-13-344

Cerezo, R., Núñez, J. C., Rosário, P., Valle, A., Rodríguez, S., \& Bernardo, A. (2010). New media for the promotion of self-regulated learning in higher education. Psicothema, 22(2), 306-315.

Considine, C., \& Dean, T. (2003). Active learning in distance education. [Conference presentation]. 2003 American Society for Engineering Education Annual Conference \& Exposition, Nashville, Tennessee, United States. https://digitalcommons.odu.edu/engtech_fac_pubs/100

Cronje, J. C. (2016). The future of our field - A STEEP perspective. TechTrends, 60(1), 5-10. https://doi.org/10.1007/s11528-015-0009-0

Czerkawski, B.C., \& Lyman, E.W. (2016). An instructional design framework for fostering student engagement in online learning environments. TechTrends, 60, 532-539. https://doi.org/10.1007/s11528016-0110-z

Dabbagh, N., \& Bannan-Ritland, B. (2005). Online learning: Concepts, strategies, and application. Pearson.

Delen, E., Liew, J., \& Willson, V. (2014). Effects of interactivity and instructional scaffolding on learning: Self-regulation in online video-based environments. Computers $\mathcal{E}$ Education, 78, 312-320. https://doi.org/10.1016/j.compedu.2014.06.018

Di Domenico, L., Pullano, G., Coletti, P., Hens, N., \& Colizza, V. (2020). Expected impact of school closure and telework to mitigate COVID-19 epidemic in France. https://www.epicxlab.com/uploads/9/6/9/4/9694133/inserm_covid-19-school-closure-french-regions_20200313.pdf

Drucker, D. J., \& Fleischhauer, K. (2021). Language pedagogy in a pandemic: The shift to online instruction at a German university during the COVID-19 crisis. Journal of Pedagogical Research, 5(1), 172-187. https://doi.org/10.33902/JPR.2021167474

Erfidan, A. (2019). Perspectives of lecturers and undergraduate students on university distance education courses: The case of Balkesir University [Unpublished master's thesis] Balıkesir University, Institute of Science.

Fairchild, A. J., Horst, S. J., Finney, S. J., \& Barron, K. E. (2005). Evaluating existing and new validity evidence for the Academic Motivation Scale. Contemporary Educational Psychology, 30(3), 331-358, https://doi.org/10.1016/j.cedpsych.2004.11.001

Felix, U. (2001). A multivariate analysis of students' experience of web based learning. Australasian Journal of Educational Technology, 17(1). https://doi.org/10.14742/ajet.1770

Frutos, R., Lopez Roig, M., Serra-Cobo, J., \& Devaux, C. A. (2020). COVID-19: the conjunction of events leading to the coronavirus pandemic and lessons to learn for future threats. Frontiers in medicine, 7, 223. https://doi.org/10.3389/fmed.2020.00223

Haar, M. (2018). Increasing sense of community in higher education nutrition courses using technology. Journal of Nutrition Education and Behaviour, 50(1), 96-99. https:// doi.org/10.1016/j.jneb.2017.04.015

Hacımustafaoğlu, M., \& Önürmen, Ö. (2018). Definition of an Outbreak (Epidemic) in infectious Diseases Practice. Journal of Pediatric Infection, 12(4), 172-173. https:/ / doi.org/10.5578/ced.201852

Hays, J. N. (2005). Epidemics and pandemics: their impacts on human history. ABC-CLIO.

Hebebci, M. T., Bertiz, Y., \& Alan, S. (2020). Investigation of views of students and teachers on distance education practices during the Coronavirus (COVID-19) Pandemic. International Journal of Technology in Education and Science (IJTES), 4(4), 267-282. 
Hirumi, A. (2002). The design and sequencing of elearning interactions: A grounded approach. International Journal on E-Learning, 1(1), 19-27.

Houser J. (2008). Nursing research: reading, using, and understanding evidence. Jones \& Bartlett.

Hung, M. L., Chou, C., Chen, C. H., \& Own, Z. Y. (2010). Learner readiness for online learning: Scale development and student perceptions. Computers $\mathcal{E}$ Education, 55(3), 1080-1090, https:// doi.org/10.1016/j.compedu.2010.05.004

Inozu, J., \& Ilin, G. (2007). How do learners perceive e-language learning programs in their local context. The Asian EFL Journal Quarterly, 9(4), 280-288.

İşman, A. (2011). Distance education (4th Ed). Pegem A Publishing

Jahng, N., Krug, D., \& Zhang, Z. (2007). Student achievement in online distance education compared to face-to-face education. European Journal of Open, Distance and E-Learning, 10(1), 253.

Jiang, Y., \& Xu, J. (2021). The association between COVID-19 deaths and short-term ambient air pollution/meteorological condition exposure: a retrospective study from Wuhan, China. Air Quality, Atmosphere \& Health, 14(1), 1-5. https:/ / doi.org/10.1007/s11869-020-00906-7

Karakış, Ö. (2020). The view of the relationshıp between university students' opinions about distance learning environments and English course success. Abant Izzet Baysal University Journal of Faculty of Education, 20(4), 1711-1728. https:/ / dx.doi.org/10.17240/aibuefd.2020.20.58249-632620

Karakuş, N., Ucuzsatar, N., Karacaoğlu, M. Ö., Esendemir, N., \& Bayraktar, D. (2020). Turkish teacher candidates' views on distance education. RumeliDE Journal of Language and Literature Studies, 19, 220-241. https://doi.org/10.29000/rumelide.752297

Karasar, N. (2006). Scientific research methods. Nobel Publishing.

Kareal, F., \& Klema, J. (2006). Adaptivity in e-learning. Current Developments in Technology-Assisted Education, 1, 260-264.

Kaufmann, R., \& Buckner, M. M. (2019). Revisiting "power in the classroom": exploring online learning and motivation to study course content. Interactive Learning Environments, 27(3), 402-409. https://doi.org/10.1080/10494820.2018.1481104

Kaufmann, R., \& Tatum, N. T. (2017). Do we know what we think we know? On the importance of replication in instructional communication research. Communication Education, 66, 479-481. https://doi.org/10.1080/03634523.2017.1342849

Kaufmann, R., \& Vallade, J. I. (2020). Exploring connections in the online learning environment: student perceptions of rapport, climate, and loneliness. Interactive Learning Environments, 1-15. https://doi.org/10.1080/10494820.2020.1749670

Klapproth, F., Federkeil, L., Heinschke, F., \& Jungmann, T. (2020). Teachers' experiences of stress and their coping strategies during COVID-19 induced distance teaching. Journal of Pedagogical Research, 4(4), 444452. https:// doi.org/10.33902/JPR.2020062805

Kaymak, Z., \& Horzum, M. (2013). Relationship between online learning readiness and structure and interaction of online learning students. Kuram ve Uygulamada Egitim Bilimleri, 13(3), 1792- 1797. https://doi.org/10.12738/estp.2013.3.1580

Laurillard, D. (2000). New technologies and the curriculum. In P. Scott. (Ed.), Higher education re-formed (pp. 133-153). Falmer Press.

Lee, K. (2020). Coronavirus: universities are shifting classes online-but it's not as easy as it sounds. The Conversation. https://theconversation.com/coronavirus-universities-are-shifting-classes-online-but-itsnot-as-easy-as-it-sounds-133030

Lesht, F. L., \& Schejbal, D. (2020). Student perceptions of required student-to-student interactions in online courses. e-Mentor, 84(2), 4-12. https://doi.org/10.15219/em84.1459

Machtmes, K. \& Asher, J. (2000). A meta-analysis of the effectiveness of telecourses in distance education. The American Journal of Distance Education, 14(1), 27-46. https:/ / doi.org/10.1080/08923640009527043

Martin, A., \& Dowson, M. (2009). Interpersonal relationships, motivation, engagement, and achievement: Yields for theory, current issues and educational practice. Review of Educational Research, 79(1), 327-365, https://doi.org/10.3102/0034654308325583

Mattar, J. (2018). Constructivism and connectivism in education technology: Active, situated, authentic, experiential, and anchored learning. Revista Iberoamericana de Educación a Distancia, 21(2), 201-217. http://dx.doi.org/10.5944/ried.21.2.20055 
Ministry of National Education [MoNE]. (2020). Bakan Selçuk, koronavirüs'e karşı eğitim alanında alınan tedbirleri açıkladı [Minister Selçuk announced the measures taken in the field of education against coronavirus] [Press release]. https://www.meb.gov.tr/bakan-selcuk-koronaviruse-karsiegitimalaninda-alinan-tedbirleri-acikladi/haber/20497/tr

Miralay, F. (2020). Evaluation of distance education practice in 2020 Covid 19 pandemic process. Near East University Online Journal of Education, 3(2), 80-86.

Moore, J. L., Dickson-Deane, C., \& Galyen, K. (2011). e-Learning, online learning, and distance learning environments: Are they the same? The Internet and Higher Education, 14(2), 129-135. https://doi.org/10.1016/j.iheduc.2010.10.001

Muthuprasad, T., Aiswarya, S., Aditya, K. S., \& Jha, G. K. (2021). Students' perception and preference for online education in India during COVID-19 pandemic. Social Sciences \& Humanities Open, 3(1), 100101. https://doi.org/10.1016/j.ssaho.2020.100101

Özkök, A., Walker, S. L., \& Büyüköztürk, Ş. (2009). Reliability and validity of a Turkish version of the DELES. Learning Environments Research, 12(3), 175-190, https://doi.org/10.1007/s10984-009-9060-0

Özüdoğru F., \& Hişmanoğlu M. (2016). Views of freshmen students on foreign language courses delivered via e-learning. Turkish Online Journal of Distance Education (TOJDE), 17(1), 31-47, https://doi.org/10.17718/tojde.18660

Parıldar, H. (2020). Infectious disease outbreaks in history. The Journal of Tepecik Education and Research Hospital, 30, 19-26. https:/ / doi.org/10.5222/terh.2020.93764

Parkes, R. S., \& Barrs, V. R. (2021). Interaction Identified as both a Challenge and a Benefit in a Rapid Switch to Online Teaching during the COVID-19 Pandemic. Journal of Veterinary Medical Education, e20200063. https:// doi.org/10.3138/jvme-2020-0063

Richardson, J. T. E., Morgan, A., \& Woodley, A. (1999). Approaches to studying distance education. Higher Education, 37, 23-55.

Roper, A. R. (2007). How students develop online learning skills. Educause Quarterly, 30(1), 62-65.

Sakarya, G., \& Zahal, O. (2020). The student opinions on distant violin education during Covid-19 epidemic. Electronic Turkish Studies, 15(6), 795-817. https:/ / dx.doi.org/10.7827/TurkishStudies.44504

Sellnow, D. D., \& Kaufmann, R. (2017). Instructional communication and the online learning environment: Then, now, and next ( $2^{\text {nd }}$ Ed). In M. L. Houser, \& A. M. Hosek (Eds.), The handbook of instructional communication: Rhetorical and relational perspectives (pp.195-206). Taylor \& Francis.

Selvi, Ö. G. Ö. (2012). Information society, information management and public relations. Gümüşhane University e-Journal of Faculty of Education, 1(3), 191-214.

Sewart, D., Keegan, D., \& Holmberg, B. (Eds.). (2020). Distance education: International perspectives. Routledge.

Shachar, M., \& Neumann, Y. (2003). Differences between traditional and distance education academic performances: A meta-analytic approach. The International Review of Research in Open and Distributed Learning, 4(2). https://doi.org/10.19173/irrodl.v4i2.153

SOU Distance Education Centre, (2009). Best practices in online course design. https://inside.sou.edu/assets/cis/distancelearning/SOU\%20DEC\%20Best\%20Practices.pdf

Srichanyachon, A. N. (2013). Attitudes of undergraduate students towards an online English course. Turkish Online Journal of Distance Education, 14(2), 225-232.

Traxler, J. (2018). Distance learning-predictions and possibilities. Education Sciences, 8(35), 1- 13, https://doi.org/10.3390/educsci8010035

Umek, L., Keržič, D., Aristovnik, A., \& Tomaževič, N. (2015). Analysis of selected aspects of students' performance and satisfaction in a Moodle-based e-learning system environment. Eurasia Journal of Mathematics, Science and Technology Education, 11(6), 1495-1505. https://doi.org/10.12973/eurasia.2015.1408a

Uşun, S. (2006). Distance education. Nobel Publishing.

Walker, S. L. (2003). Development and validation of an instrument for assessing distance education learning environments in higher education: The Distance Education Learning Environments Survey (DELES). [Unpublished doctoral dissertation], Curtin University of Technology, Perth, Australia. http:/ / adt.curtin.edu.au/theses/available/adt-WCU20040211.095711/.

Wallace, R. M. (2003). Online learning in higher education: A review of research on interactions among teachers and students. Education, Communication $\mathcal{E}$ Information, 3(2), 241-280. https://doi.org/10.1080/14636310303143 
Wayne S. J., Fortner S. A., Kitzes, J. A., Timm, C. \& Kalishman S. (2013). Cause or effect? The relationship between student perception of the medical school learning environment and academic performance on USMLE Step 1. Med Teach. 35(5), 376-380. https:/ / doi.org/10.3109/0142159X.2013.769678

Weinhandl, R., Lavicza, Z., Hohenwarter, M. \& Schallert, S. (2020). Enhancing flipped mathematics education by utilising GeoGebra. International Journal of Education in Mathematics, Science and Technology, 8(1), 1-15. https:// doi.org/10.46328/ijemst.v8i1.832

Zhang, W., Wang, Y., Yang, L., \& Wang, C. (2020). Suspending Classes Without Stopping Learning: China's Education Emergency Management Policy in the COVID-19 Outbreak. Journal of Risk and Financial Management, 13(3), 55. https:// doi.org/10.3390/jrfm13030055

Zhao, Y., Lei, J., Yan, B., Lai, C., \& Tan, H. S. (2005). What makes the difference? A practical analysis of research on the effectiveness of distance education. Teachers College Record, 107(8), 1836-1884. https://doi.org/10.1111/j.1467-9620.2005.00544.x 